\title{
Impact of Senior Management Support, Employees' Involvement, and Open Corporate Culture on The Motivation of Employees: An Empirical Study
}

\begin{abstract}
Sadia Kausar ${ }^{1}$
Abstract

This study is aimed to investigate the impact of senior management support, employees' involvement and open corporate culture on the motivation of employees' motivation by using the education sector as a study area. This paper is an empirical study and its primary data is collected through a questionnaire. The sample size of this study consists of two hundred employees (hundred from public and hundred from private institutes). Correlation and regression analysis are used to test the hypothesis of the study. The findings of the study show that employees' motivation mainly depends upon senior management support and employees' involvement in decision making. On the other side, open corporate culture has no significant impact on employees' motivation. The study, therefore, recommends that organizations should include some practical tools that can increase their employees' motivation.
\end{abstract}

Keywords: Senior management support, employees' involvement, open corporate culture, employees' motivation, education sector

JEL Classification: M1, M2, M20, M3, M30, M31, M32, M4, M5, M6, M7, M8, M9

\section{Introduction}

This research study concerns with the various factors that may affect the motivation of employees. These variables are senior management support, employees' involvement, open corporate culture, and employees' motivation. Although employee motivation has been the focus of various previous researches but still the most daunting task of organizational experts, business scholars and managers are how to put together and utilize their human and material resources to achieve the organizational objectives (Olusadum \& Anulika, 2018). Further, they proved that employee motivation has a

\footnotetext{
${ }^{1}$ Instructor, Department of Management Sciences, Virtual University of Pakistan Corresponding Author: sadia.kausar@vu.edu.pk
} 
Sadia Kausar. Impact of Senior Management Support, Employees' Involvement, and Open Corporate Culture on The Motivation of Employees: An Empirical Study

significant relationship with employee performance. As per the study of Jensen (2018), leaders play an important role in motivating their employees, to achieve high performance and organizational goals.

Senior management support, employee empowerment/ involvement, the teamwork of employees and open corporate culture are the cultural factors that are directly linked with total quality practices in the organization (Adebanjo \& Kehoe, 1999). They further argued that these cultural factors merge structural dimensions, cultural elements \& competencies into one context which ultimately supports all stakeholders for developing their visions, values, and beliefs. For getting good business results, employees' involvement in decision making, employees' teamwork, and better management play a key role (Haupt \& Whiteman, 2004). As per the study of Haynie and Mossholder (2016), senior managers should share information with their employees and involve them in decision making if they want to minimize negative perceptions of employees especially concerning changes in the organization. Moreover, senior managers will be able to maintain the motivating potential of behavioral control of employees.

This research study covers the service sector, particularly the education sector.

Three main hypotheses are developed: (1) Relationship of senior management support with employees' motivation; (2) Employees' involvement in decision making increases the motivation of employees; (3) Open corporate culture relates to the employees' motivation. The main objective of this study is to see the impact of senior management support, employees' involvement and open corporate culture on the motivation of employees. This study will provide help to educational institutes and leaders to motivate their employees and to understand the importance of motivational factors as no previous research is available with these independent variables. So, if employees' motivation is not properly handled then organizations will always endure negative attitudes of employees towards work.

\section{Literature Review}

Organizational culture refers to the values, attitudes, beliefs, and norms that are shared by its members which mean that how its members behave with each other and with outsiders (Robbin \& Coulter, 2003). As per the study of Saha and Hardie (2005), an organization with quality culture endorses leadership rather than supervision; inspires commitment in its staff, encourages teamwork, promotes employees' empowerment \& eliminates fear, instill pride in employees and promotes employees to seek continuous improvements.

According to management literature, employees are the most valuable asset of the organizations and they act as a key player for achieving organizational goals (Judge \& Ilies, 2002; Rainey, 1997). The study of Olusola (2011) proved that motivation is an essential mechanism for regulating the work behaviors of employees. As per the study of Olusadum and Anulika (2018), the most challenging task for organizational experts and managers is to utilize and motivate their human resources. Moreover, senior managers play an important role in motivating their employees and to achieve

Sukkur IBA Journal of Management and Business - SIJMB | Vol 6 No. 2 July - December 2019 @ Sukkur IBA University 
Sadia Kausar. Impact of Senior Management Support, Employees' Involvement, and Open Corporate Culture on The Motivation of Employees: An Empirical Study

organizational goals (Jensen, 2018). Fiaz and Saqib (2017) proved that a supportive leadership style helps to increase the motivation of employees. Employees' performance and productivity can be improved if top management provides a suitable work environment and comfort to their employees (Leiter \& Maslach, 2002). Usually, senior managers make strategic decisions that directly affect organizations' internal policies and culture. And employees of the organizations are influenced due to these senior management decisions and actions (Barrick, Thurgood, Smith, \& Courtright, 2015)

To boost up the employees' motivation, leaders are required to demonstrate personal courage, express confidence in others and trust on abilities of their workers (Webb, 2007). Moreover, he proved that employees show motivation towards extra efforts only when their leaders possess self-confidence, power, high energy, and assertiveness in them. Organizations have an influencing link between leaders and their followers with the true intention of genuine transformation (Daft, 2014). Some previous researches revealed a direct relationship between leadership and employees' work-related attitudes as well as efforts such as job involvement, career satisfaction, and organizational commitment (De Groot et al., 2000; De Hoogh et al., 2005). As per the study of Jensen (2018), leaders have the cardinal responsibility of determining what motivates their employees. Moreover, he viewed that leaders must spend time with their employees in order to build close relationships and to know their employees on an intimate level to determine what motivates them.

Empowerment or involvement refers to the improved intrinsic task motivation. Kyoon et al., (2006) define employee empowerment as the degree to which a group of employees participates in decision making. Employees' involvement in business decisions has a positive impact on internal business conditions and organization performance (Lawler et al., 1992). Chan et al., (2004) believe that organizations should involve employees in decision making and process improvement activities by encouraging their participation. This involvement provides them with an increased sense of ownership and responsibility. Organizations that use employee education programs observe visible improvements in their employees' abilities (Cebeci \& Beskese, 2002). Employees' job satisfaction and motivation are linked with the employees' perceived empowerment (Byza, Dorr, Schuk \& Maier, 2019). The study of Ukil (2016) viewed that employees' satisfaction significantly depends on employees' empowerment and then these satisfied employees provide quality services.

Corporate culture can impact the motivational perspective of employees (Shore \& Wayne, 1993). Power distribution between employees of the organization builds an open corporate culture and allows employees to control their work activities (Ambroz, 2004). Oakland (2014) believed that a key medium of employees' motivation towards quality service efforts is one to one communication and visible management commitment. Adebanjo and Kehoe (1999) viewed that organizations with quality culture presented a better level of interdepartmental co-operation, workforce flexibility, and a "flatter" management structure. Organizations can improve empowerment in their employees by developing an organizational learning environment; and especially focus on their motivation towards work (Sadeghifer et al., 2014). La Motta (1995)

Sukkur IBA Journal of Management and Business - SIJMB | Vol 6 No. 2 July - December 2019 @ Sukkur IBA University 
Sadia Kausar. Impact of Senior Management Support, Employees' Involvement, and Open Corporate Culture on The

believed that there is a strong need for such managers in the organizations who must learn to motivate their employees.

Most of the employees are motivated in their organization due to various factors such as pleasant working environment, the culture of mutual respect, feeling of prestige and self-respect, the provisions of adequate leisure time and involvement (Merchant et al., 2003). Recognition is considered a first step for increasing the employees' involvement in work activities (Kemp et al., 1997). For achieving quality in employees' performance, educational institutes should provide their employees a dynamic and advanced employee' training programs (Mohd, 2012). Perry and Wise (1990) viewed that public organizations need to reframe the level of motivation in their employees. Schein (1980) believed that employees usually feel motivation towards their work whenever they get what they need from their job and they respond positively when top management fulfills their needs (Mayo, 2014).

The organizational theory refers to the set of interrelated concepts that depict the behavior of employees who interacts with each other to perform the activities projected towards the accomplishment of goals. The Neoclassical theory states that employees are distinctly motivated and they want to fulfill their certain needs. The premise of this study is based on the idea that the key role of senior management is to utilize their employees to get things done in the organizations. Rather than focus on the structure of the organization, the neoclassical theory is concerned with the employees and their motivation towards work. Neoclassical theory is concerned about to find the best ways that help leaders to motivate and support their employees within the organization (Neoclassical Theory of Management: The Human Relations Approach, 2012).

Moreover, Hawthorne studies revealed that employees' relationships with their colleagues and bosses are more important factors for managers to consider. It is also assumed that managers who failed to consider the social needs of their employees could expect to deal with resistance and employees' lower performance.

\subsection{Theoretical Framework}

The motivational factor behind this study is to find the influence of senior management support, employees' involvement and open corporate culture on the motivation of employees especially working in educational institutes of Pakistan. From the previous research, sub-elements are used for measuring the dimensions of independent and dependent variables. IVs and DV are measured by keeping in view the belowmentioned dimensions:

Sukkur IBA Journal of Management and Business - SIJMB | Vol 6 No. 2 July - December 2019 @ Sukkur IBA University 
Sadia Kausar. Impact of Senior Management Support, Employees' Involvement, and Open Corporate Culture on The

Table 1: Variable dimensions

\begin{tabular}{|l|l|l|}
\hline Variable & \multicolumn{1}{|c|}{ Dimension } & \multicolumn{1}{c|}{ Author } \\
\hline $\begin{array}{l}\text { Senior management } \\
\text { support }\end{array}$ & $\begin{array}{l}\text { Education } \\
\text { Training } \\
\text { Involvement } \\
\text { Reward \& recognition }\end{array}$ & $\begin{array}{l}\text { Adebanjo and Kehoe } \\
(1999)\end{array}$ \\
\hline Employee involvement & $\begin{array}{l}\text { Empowerment } \\
\text { Encouragement } \\
\text { Team orientation } \\
\text { Capability development }\end{array}$ & $\begin{array}{l}\text { Adebanjo and Kehoe } \\
(1999)\end{array}$ \\
\hline Open corporate culture & $\begin{array}{l}\text { Communication } \\
\text { Organizational structure } \\
\text { Recreation }\end{array}$ & $\begin{array}{l}\text { Adebanjo and Kehoe } \\
(1999)\end{array}$ \\
\hline Employee motivation & $\begin{array}{l}\text { Working conditions } \\
\text { Work contents } \\
\text { Personal interest } \\
\text { Leader/supervisor }\end{array}$ & Roshan (2005) \\
& \multicolumn{2}{|l}{} \\
& \multicolumn{2}{|l}{} \\
& & \\
& & \\
& & \\
&
\end{tabular}

Figure 1 displays the theoretical framework of this study. Here in this study senior management support, employees' involvement and open corporate culture are considered as independent variables while employees' motivation is considered as a dependent variable. $\mathrm{X}$ denotes independent variables while $\mathrm{Y}$ denotes a dependent variable.

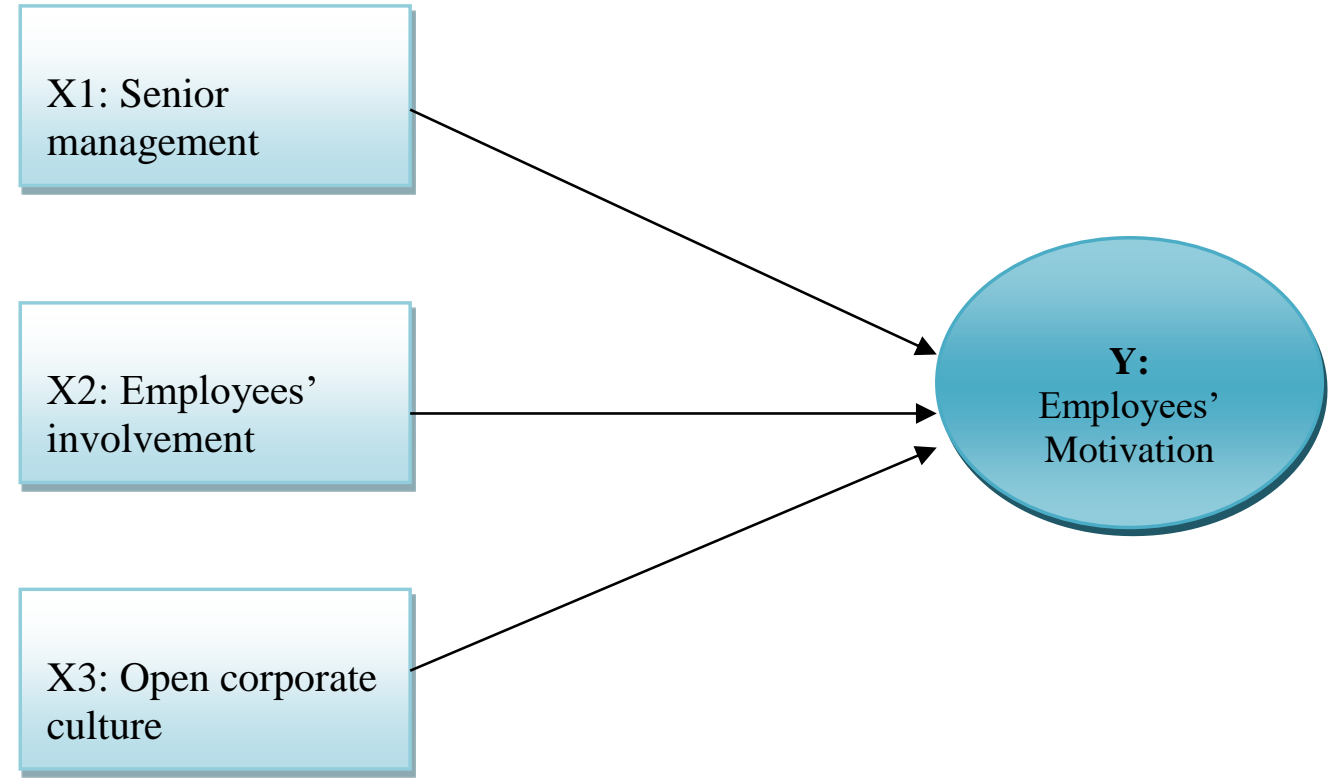

Figure 1: Conceptual framework of the study

Sukkur IBA Journal of Management and Business - SIJMB | Vol 6 No. 2 July - December 2019 ๑ Sukkur IBA University 103 
Sadia Kausar. Impact of Senior Management Support, Employees' Involvement, and Open Corporate Culture on The

Motivation of Employees: An Empirical Study

(pp. 99-113)

Hypotheses

Based on the literature review following hypotheses are made:

H1: Support of senior management to employees has a significant positive impact on employees' motivation.

H2: Employees' involvement in decision making has a significant positive impact on employees' motivation.

H3: Open corporate culture of the organization has a significant impact on employees' motivation.

\section{Research Methodology}

Above mentioned literature mentioned that various studies show the influence of senior management support, employees' involvement and open culture on employees' motivation. The current study is conducted in public and private universities of Lahore based on surveys. Three public and two private universities of Lahore are used for studying the employees' motivation concerning senior management support, employees' involvement and open corporate culture.

\subsection{Research Instrument}

Data has been gathered through primary sources as well as from secondary sources. A self-administrated questionnaire has been used to collect primary data. The instrument uses a -5-point Likert scale from 1-strongly disagree, 2-disagree, 3-neutral, 4-agree, and 5-strongly agree. These questionnaires show the opinions of employees concerning each question. The questionnaire included 25 questions and some respondents' demographic questions. Overall seven questions relate to senior management support, five to employees' involvement, six to open corporate culture and seven relate to employees' motivation. Data is collected only once so this study is based on crosssectional analysis.

\subsection{Sample}

The study used non-probability sampling and it is further categorized into convenience sampling. The total population of three public and two private universities of Lahore is 1200 while the sample size of this study is 250 . Respondents of this study are employees (all types of academic and non-academic employees). According to Nunnally (1978), at least 10 or more respondents per item of the questionnaire are reasonably adequate for sample size. Out of 250 questionnaires, 200 respondents are responded and make a response rate of $80 \%$.

\subsection{Reliability of Measure}

To identify the reliability of variables, Cronbach's alpha coefficient value for each variable is calculated. The accepted value of Cronbach alpha is at least 0.70 or above (Cronbach, 1951). By using SPSS-X statistical package Cronbach alpha values are calculated. Cronbach alpha values for all variables are: open corporate culture: 0.71 ;

Sukkur IBA Journal of Management and Business - SIJMB | Vol 6 No. 2 July - December 2019 @ Sukkur IBA University 
Sadia Kausar. Impact of Senior Management Support, Employees' Involvement, and Open Corporate Culture on The Motivation of Employees: An Empirical Study

employees' involvement: 0.70 ; senior management support: 0.78 and employees' motivation: 0.8. All Cronbach alpha values are well above the satisfactory threshold value of 0.70 , it means the questionnaire has good reliability.

\section{Data Analysis and Hypotheses Testing}

The data is first subjected to the principal components factor analysis (CFA) to check the validity and reliability of the different factors involved in this study. All the responses from the questionnaire are coded in SPSS software and hypothesis are tested with the help of correlation and regression analysis.

Table 2: Work experience in years

\begin{tabular}{|r|l|r|r|r|r|}
\hline \multicolumn{2}{|c|}{} & Frequency & Percent & Valid Percent & \multicolumn{2}{c|}{$\begin{array}{c}\text { Cumulative } \\
\text { Percent }\end{array}$} \\
\hline \multirow{7}{*}{ Valid } & $1-5$ & 154 & 77.0 & 77.0 & 77.0 \\
\cline { 2 - 6 } & $6-10$ & 40 & 20.0 & 20.0 & 97.0 \\
\cline { 2 - 6 } & $11-15$ & 3 & 1.5 & 1.5 & 98.5 \\
\cline { 2 - 6 } & $16-20$ & 2 & 1.0 & 1.0 & 99.5 \\
\cline { 2 - 6 } & Above 26 & 1 & .5 & .5 & 100.0 \\
\cline { 2 - 6 } & Total & 200 & 100.0 & 100.0 & \\
\hline
\end{tabular}

Table 2 shows that overall 154 respondents are having 1 to 5 years of work experience and 40 respondents are having 6 to 10 years of work experience.

Table 3: Descriptive statistics

\begin{tabular}{|l|c|c|c|c|c|c|}
\hline & $\mathrm{N}$ & Mini & Max & Mean & $\begin{array}{c}\text { Std. } \\
\text { Deviation }\end{array}$ & Variance \\
\hline Age & 200 & 1 & 3 & 2.06 & 0.639 & 0.408 \\
\hline $\begin{array}{l}\text { Senior_management_su } \\
\text { pport }\end{array}$ & 200 & 1 & 5 & 2.56 & 0.793 & 0.628 \\
\hline Employee_involvement & 200 & 1 & 5 & 2.36 & 0.734 & 0.539 \\
\hline $\begin{array}{l}\text { Open_corporate_cultur } \\
\text { e }\end{array}$ & 200 & 1 & 5 & 2.51 & 0.722 & 0.521 \\
\hline Motivation & 200 & 1 & 5 & 2.50 & 0.725 & 0.526 \\
\hline
\end{tabular}

Table 3 presents that all $\mathrm{N}$ values are valid for dependent and independent variables. Mean values for senior management support, employees' involvement, open corporate culture and employees' motivation are 2.56, 2.36, 2.51 and 2.50 respectively. Standard deviation values for dependent and independent variables range from 0.722 to 0.793 .

Sukkur IBA Journal of Management and Business - SIJMB | Vol 6 No. 2 July - December 2019 (c) Sukkur IBA University 
Sadia Kausar. Impact of Senior Management Support, Employees' Involvement, and Open Corporate Culture on The

Table 4: Correlation Analysis

\begin{tabular}{|c|c|c|c|c|c|}
\hline & & Motivation & $\begin{array}{l}\text { Open } \\
\text { Corporate } \\
\text { Culture }\end{array}$ & $\begin{array}{l}\text { Employee } \\
\text { Involvement }\end{array}$ & $\begin{array}{c}\text { Senior } \\
\text { Management } \\
\text { Support }\end{array}$ \\
\hline Motivation & $\begin{array}{l}\text { Pearson } \\
\text { Correlation }\end{array}$ & & $.564^{* *}$ & $.554^{* *}$ & $.748^{* *}$ \\
\hline & Sig. (2-tailed) & & .000 & .000 & .000 \\
\hline $\begin{array}{l}\text { Open } \\
\text { Corporate }\end{array}$ & $\begin{array}{l}\text { Pearson } \\
\text { Correlation }\end{array}$ & $.564^{* *}$ & & $.358^{* *}$ & $.640^{* * *}$ \\
\hline Culture & Sig. (2-tailed) & .000 & & .000 & .000 \\
\hline $\begin{array}{l}\text { Emp. } \\
\text { Involvement }\end{array}$ & $\begin{array}{l}\text { Pearson } \\
\text { Correlation }\end{array}$ & $.554^{* *}$ & $.358^{* *}$ & & $.426^{* *}$ \\
\hline & Sig. (2-tailed) & .000 & .000 & & .000 \\
\hline $\begin{array}{l}\text { Senior } \\
\text { Management }\end{array}$ & $\begin{array}{l}\text { Pearson } \\
\text { Correlation }\end{array}$ & $.748^{* *}$ & $.640^{* *}$ & $.426^{* *}$ & \\
\hline Support & Sig. (2-tailed) & .000 & .000 & .000 & \\
\hline
\end{tabular}

It is reported by table 4, there is a positive correlation found between senior management support, employees' involvement and employees' motivation. On the other hand, there is also a positive correlation found between open corporate culture and employees' motivation. Correlation values normally remain in +1 and -1 . A value near +1 shows a strong positive correlation and near -1 shows a strong negative correlation. The correlation value of open corporate culture with employees' motivation is 0.564 which shows moderate and positive correlation.

The correlation coefficient value of employees' involvement with employees' motivation is 0.554 which also shows moderate and positive correlation. On the other hand, correlation value of senior management support with employees' motivation is 0.748. It shows that senior management support has a strong and positive correlation with employees' motivation.

Table 5: Regression Model Summary

\begin{tabular}{|l|c|c|c|c|}
\hline Model & $\mathrm{R}$ & R Square & Adjusted R Square & Std. Error of the Estimate \\
\hline 1 & $.796 \mathrm{a}$ & .634 & .628 & .442 \\
\hline
\end{tabular}

a) Predictors: (Constant), senior management support, employee involvement and open corporate culture 
Sadia Kausar. Impact of Senior Management Support, Employees' Involvement, and Open Corporate Culture on The Motivation of Employees: An Empirical Study

In the regression model table 5, R-value shows multiple correlations between independent and dependent variables. The multiple correlations between the predictors (senior management support, employees' involvement, and open corporate culture) and the dependent variable (employees' motivation) is 0.796 , thus there is a strong positive correlation exist between the variables. $\mathrm{R}$ square value shows the ratio of variance in the dependent variable solely or jointly due to independent variables; the value of 0.634 shows that senior management support, employees' involvement, and open culture account for $63.4 \%$ of the variation in employees' motivation.

Table 5(a): ANOVA

\begin{tabular}{|l|l|c|c|c|c|c|}
\hline \multicolumn{2}{|l|}{ Model } & $\begin{array}{c}\text { Sum of } \\
\text { Squares }\end{array}$ & df & Mean Square & F & Sig. \\
\hline 1 & Regression & 66.301 & 3 & 22.100 & 112.994 & $.000^{\text {a }}$ \\
\cline { 2 - 7 } & Residual & 38.335 & 196 & .196 & & \\
\cline { 2 - 7 } & Total & 104.636 & 199 & & & \\
& & & & & & \\
\hline
\end{tabular}

a) Predictors: (Constant), Open_corporate_culture, Employees'_involvement, Senior_management_support

b) Dependent Variable: Motivation

The results of the study and hypotheses testing are primarily based on the values of Table 5(a) and Table 5(b). ANOVA (Analysis of variance) table displays that the effect of independent variables (predictor) on the dependent variable is statistically significant which is below 0.05. ANOVA indicated that the model is reliable and best fitted at all conventional levels of significance. As per table 5 (a), the p-value is less than 0.05 . So the overall model of the study is significant. As per Table 5(b), beta and standard error values are deviating from variable to variable. The significance of open corporate culture is low, i.e. 0.068

The study recommends that senior management support and employees' involvement have a significant positive association with employees' motivation. However, the analysis proved that the values do not support a significant association between open corporate culture and employees' motivation. This incongruity is comprehensible as open corporate culture hardly motivates employees towards work; there are some other factors that more significant impact on employees' motivation. 
Table 5(b): Coefficients

\begin{tabular}{|c|c|c|c|c|c|c|}
\hline \multirow[b]{2}{*}{ Model } & \multicolumn{2}{|c|}{$\begin{array}{l}\text { Unstandardized } \\
\text { Coefficients }\end{array}$} & \multirow{2}{*}{$\begin{array}{c}\text { Standardized } \\
\text { Coefficients } \\
\text { Beta }\end{array}$} & \multirow[b]{2}{*}{$\mathrm{t}$} & \multirow[b]{2}{*}{ Sig. } & \multirow[b]{2}{*}{$\begin{array}{c}\text { Hypotheses } \\
\text { Testing } \\
\text { Decision }\end{array}$} \\
\hline & B & $\begin{array}{l}\text { Std. } \\
\text { Error }\end{array}$ & & & & \\
\hline 1 (Constant) & .270 & .133 & & $\begin{array}{l}2.0 \\
26\end{array}$ & $\begin{array}{c}.04 \\
4\end{array}$ & \\
\hline $\begin{array}{l}\text { Senior_management_suppor } \\
\mathrm{t}\end{array}$ & .516 & .054 & .564 & $\begin{array}{l}9.6 \\
42 \\
\end{array}$ & $\begin{array}{c}.00 \\
0\end{array}$ & Significant \\
\hline Employee_involvement & .273 & .048 & .276 & $\begin{array}{l}5.7 \\
36\end{array}$ & $\begin{array}{c}.00 \\
0\end{array}$ & Significant \\
\hline Open_corporate_culture & .105 & .057 & .104 & $\begin{array}{l}1.8 \\
38\end{array}$ & .06 & Insignificant \\
\hline
\end{tabular}

a) Dependent Variable: Emp. Motivation

The results of the hypotheses are:

H1: Support of senior management to employees has a significant positive impact on employees' motivation.

H2: Employees' involvement in decision making has a significant positive impact on employees' motivation.

H3: Open corporate culture of the organization does not have a significant positive impact on employees' motivation.

\section{Discussion}

The current study has achieved its objectives of providing insights into the relationship between senior management support, employees' involvement, and employees' motivation. Both independent variables have a significant positive relationship with employees' motivation especially working in the education sector. Senior managers play a direct role in employees' motivation and they help them to achieve organizational goals (Jensen, 2018). According to the study of Barrick et al., (2015), employees are directly influenced by the senior managers' decisions and actions. Moreover, a supportive leadership style enhances the motivation of employees (Fiaz \& Saqib, 2017). Bass (1985) proved that senior managers who give negative feedback to employees do not facilitate their personal growth and increase the motivation of employees. According to Yammarino and Bass (1990), only effective leaders help subordinates to raise their motivation toward extra efforts in the job. Leiter and Maslach (2002) proved that employees' performance and productivity can be improved if top management provides support and a suitable work environment for them. Hence, senior management support improves the motivation of employees and ultimately employees better perform their work responsibilities in the organizations.

Sukkur IBA Journal of Management and Business - SIJMB | Vol 6 No. 2 July - December 2019 @ Sukkur IBA University 
Sadia Kausar. Impact of Senior Management Support, Employees' Involvement, and Open Corporate Culture on The Motivation of Employees: An Empirical Study

Employees' involvement in key decisions helps organizations to enhance the motivation of their employees. Pascale et al., (1997) believed that the involvement of employees in the organizational decisions is the most important function of management in implementing change. Employees' involvement in business decisions has a positive and direct impact on employees' motivation and organization performance (Lawler et. al., 1992). Employees' motivation and job satisfaction are associated with the employees' perceived empowerment in decision making (Byza, Dorr, Schuk \& Maier 2019). Thus, employees' satisfaction and motivation significantly depend on employees' involvement in decision making (Ukil, 2016). Chan et al. (2004) suggested that organizations should involve employees in decision making and process improvement activities by encouraging their participation.

According to data analysis, open corporate culture has an insignificant effect on the motivation of employees. Evidence shows that many other factors impact on employees' motivation more significantly. Those organizations that have a learning culture encourage and support a higher motivation level of employees (Pool, 2000).

\section{Conclusion}

This research study is focused on senior management support, employees' involvement, open corporate culture and employees' motivation. Senior management support and employees' involvement have a positive relationship with employees' motivation. Hence, management support leads to the increased motivation of employees towards their work. So, supervisors or heads of the departments should support their subordinates and motivate them to participate in decision making. Motivated employees are more productive rather than productive employees are motivated. All level employees of the education sector should be considered as valuable assets of their respective organizations. This study further suggested that employees' motivation have key importance for the organization's success

\section{An Implication of the Study}

The findings of this research study are context-specific but they are in line with the theoretical assumptions of senior management support and employees' involvement in decision making (Jensen, 2018 and Byza et al., 2019) but inconsistent with open corporate culture (Pool, 2000). This study has broader practical implications for researchers and academicians to better understand the factors that impact on the motivation of employees. The findings can be helpful for the educational institutes and senior management to understand the importance of employees' motivation, and how they can modify their practices to make it further result oriented. This study provides a strong base for existing literature and offers fertile areas for further future researches. Furthermore, educational institutes need to motivate their employees by giving them management support and empowerment. These institutes need to build an open culture that contains one to one communication and a supportive work environment.

The findings of this research study are less generalizable because the sample size is restricted to only educational institutes. Future researches may embrace some other

Sukkur IBA Journal of Management and Business - SIJMB | Vol 6 No. 2 July - December 2019 (c) Sukkur IBA University 
Sadia Kausar. Impact of Senior Management Support, Employees' Involvement, and Open Corporate Culture on The Motivation of Employees: An Empirical Study

sectors and perform comparative analysis. Moreover, this study indicates a strong need to discover some other possible contextual factors that influence the motivation of employees.

\section{References:}

Adebanjo, D., \& Kehoe, D. (1999). An investigation of quality culture development in UK industry. International Journal of Operations \& Production Management, 19(7), 633-650.

Ambroz, M., Ambrož, M., \& Ambrož, M. (2004). Total quality system as a product of the empowered corporate culture. The TQM magazine, 16(2), 93-104.

Bass, B. M., \& Bass Bernard, M. (1985). Leadership and performance beyond expectations.

Barrick, M. R., Thurgood, G. R., Smith, T. A., \& Courtright, S. H. (2015). Collective organizational engagement: Linking motivational antecedents, strategic implementation, and firm performance. Academy of Management journal, 58(1), 111-135.

Byza, O. A., Dörr, S. L., Schuh, S. C., \& Maier, G. W. (2019). When leaders and followers match: the impact of objective value congruence, value extremity, and empowerment on employee commitment and job satisfaction. Journal of Business Ethics, 158(4), 1097-1112.

Cebeci, U., \& Beskese, A. (2002). An approach to the evaluation of quality performance of the companies in Turkey. Managerial Auditing Journal, 17(1/2), 92-100.

Chan, L. L., Shaffer, M. A., \& Snape, E. (2004). In search of sustained competitive advantage: the impact of organizational culture, competitive strategy and human resource management practices on firm performance. The International Journal of Human Resource Management, 15(1), 17-35.

Cronbach, L. J. (1951). Coefficient alpha and the internal structure of tests. psychometrika, 16(3), 297-334.

Daft, R. L. (2014). The leadership experience. Cengage Learning.

DeGroot, T., Kiker, D. S., \& Cross, T. C. (2000). A meta-analysis to review organizational outcomes related to charismatic leadership. Canadian Journal of Administrative Sciences/Revue Canadienne des Sciences de l'Administration, 17(4), 356-372.

De Hoogh, A. H., Den Hartog, D. N., Koopman, P. L., Thierry, H., Van den Berg, P. T., Van der Weide, J. G., \& Wilderom, C. P. (2005). Leader motives, charismatic leadership, and subordinates' work attitude in the profit and voluntary sector. The Leadership Quarterly, 16(1), 17-38.

Fiaz, M., Su, Q., \& Saqib, A. (2017). Leadership styles and employees' motivation: Perspective from an emerging economy. The Journal of Developing Areas, 51(4), 143-156.

Haupt, T. C., \& Whiteman, D. E. (2004). Inhibiting factors of implementing total quality management on construction sites. The TQM magazine, 16(3), 166173.

Sukkur IBA Journal of Management and Business - SIJMB | Vol 6 No. 2 July - December 2019 @ Sukkur IBA University 
Sadia Kausar. Impact of Senior Management Support, Employees' Involvement, and Open Corporate Culture on The

Haynie, J. J., Mossholder, K. W., \& Harris, S. G. (2016). Justice and job engagement: The role of senior management trust. Journal of Organizational Behavior, 37(6), 889-910.

Jensen, J. D. (2018). Employee motivation: A leadership imperative. International Journal of Business Administration, 9(2), 93-98.

Judge, T. A., \& Ilies, R. (2002). Relationship of personality to performance motivation: A meta-analytic review. Journal of applied psychology, 87(4), 797.

Kemp, A., Pryor, S., \& Dale, B. (1997). Sustaining TQM: a case study at Aeroquip Iberica. The TQM Magazine, 9(1), 21-28.

Kyoon Yoo, D., Subba Rao, S., \& Hong, P. (2006). A comparative study on cultural differences and quality practices-Korea, USA, Mexico, and Taiwan. International Journal of Quality \& Reliability Management, 23(6), 607-624.

LaMotta, T. (1995). Recognition: The quality way. New York: Quality Resources.

Lawler, E. E., Mohrman, S. A., \& Ledford, G. E. (1992). Employee involvement and total quality management: Practices and results in Fortune 1000 companies. Jossey-Bass Inc Pub.

Leiter, M. \& Maslach, C. (2002). Beating burnout, Human Resource Management International Digest, 10(1), 6-9.

Mayo, E. (2014). The social problems of an industrial civilisation. Routledge.

Merchant, K. A., Van der Stede, W. A., \& Zheng, L. (2003). Disciplinary constraints on the advancement of knowledge: the case of organizational incentive systems. Accounting, Organizations and Society, 28(2-3), 251-286.

Mohd Ali, H., \& Borhandden Musah, M. (2012). Investigation of Malaysian higher education quality culture and workforce performance. Quality Assurance in Education, 20(3), 289-309.

Neoclassical Theory of Management: The Human Relations Approach. (2012, December 20). Retrieved from https://study.com/academy/lesson/neoclassical-theory-of-management-the-human-relations-approach.html.

Nunnally, J. (1978). Psychometric methods.

Oakland, J. S. (2014). Total quality management and operational excellence: text with cases. Routledge.

Olusadum, N. J., \& Anulika, N. J. (2018). Impact of Motivation on Employee Performance: A Study of Alvan Ikoku Federal College of Eduaction. sigma, 1, 1.

Olusola, O. (2011). INTINSIC MOTIVATION, JOB SATISFACTION AND SELFEFFICACY AS PREDICTORS OF JOB PERFORMANCE OF INDUSTRIAL WORKERS IN IJEBU ZONE OF OGUN STATE. Journal of international social research, 4(17): 570-577.

Pascale, R., Millemann, M., \& Gioja, L. (1997). Changing the way we change. Harvard Business Review, 75(6), 126.

Perry, J. L., \& Wise, L. R. (1990). The motivational bases of public service. Public administration review, 367-373.

Sukkur IBA Journal of Management and Business - SIJMB | Vol 6 No. 2 July - December 2019 (c) Sukkur IBA University 
Sadia Kausar. Impact of Senior Management Support, Employees' Involvement, and Open Corporate Culture on The

Pool, S. W. (2000). The learning organization: motivating employees by integrating TQM philosophy in a supportive organizational culture. Leadership \& Organization Development Journal, 21(8), 373-378.

Rainey, H. G. (1997). Understanding and managing public organizations. Jossey-Bass, San Francisco, CA.

Robbins, S. \& Coulter, M. (2003). Management. Upper Saddle River, nj: Prentice-Hall.

Roshan, L. R. (2005). The relationship between rewards, recognition and motivation at an Insurance Company in the Western Cape. Unpublished Masters Thesis. University of Western Cape.

Sadeghifar, J., Ashrafnejad, F., Mousavi, S. M., Nasiri, A. B., Vasokolaei, G. R., Zadeh, K. N., ... \& Nasiri, M. B. (2014). The relationship between organizational learning and staff empowerment in hospital: A correlational study in Iran. Asian Social Science, 10(16), 27.

Saha, S., \& Hardie, M. (2005). Culture of quality and the Australian construction industry. In 13th International Group for Lean Construction Conference: Proceedings (p. 531). International Group on Lean Construction.

Schein, E. H. (1980). Organizational psychology (3d ed). Prentice-Hall, Englewood Cliffs, N.J

Shore, L. M., \& Wayne, S. J. (1993). Commitment and employee behavior: Comparison of affective commitment and continuance commitment with perceived organizational support. Journal of applied psychology, 78(5), 774.

Ukil, M. I. (2016). The impact of employee empowerment on employee satisfaction and service quality: Empirical evidence from financial enterprizes in Bangladesh. Verslas: teorija ir praktika, 17(2), 178-189.

Webb, K. (2007). Motivating peak performance: Leadership behaviors that stimulate employee motivation and performance. Christian Higher Education, 6(1), 5371.

Yammarino, F. J., \& Bass, B. M. (1990). Transformational leadership and multiple levels of analysis. Human relations, 43(10), 975-995.

\section{Senior management support}

\section{Annexure}

- I believe that senior management is capable enough to understand employees' problems.

- Management believes that continual training and upgrading of employee skills are important.

- I believe that our management offers sufficient job training for employees.

- Strategic planning is ongoing and management involves everyone in the process to some degree.

- I believe that employees are promoted in a fair and honest way.

- My supervisor always recognized me for good work.

Sukkur IBA Journal of Management and Business - SIJMB | Vol 6 No. 2 July - December 2019 @ Sukkur IBA University 
Sadia Kausar. Impact of Senior Management Support, Employees' Involvement, and Open Corporate Culture on The

- My supervisor cares about my personal needs.

\section{Open corporate culture}

- I believe that in my organization two-way communications is present.

- It is easy to communicate across different departments of the organization.

- The overall atmosphere existing in my organization is open and friendly.

- People in my organization have the opportunity to be involved in the decision-making process.

- I believe that my organization structure encourages the free exchange of information and ideas.

- Employees are always facilitated to go on trip for refreshment purposes.

\section{Employee involvement}

- Most employees are highly involved in their work.

- Information is widely shared so that everyone can get the information he or she needs when it's needed.

- People work like they are part of a team.

- Teamwork is used to get work done rather than hierarchy.

- Work is organized so that each person can see the relationship between his or her job and the goals of the organization.

\section{Motivation}

- I receive training frequently which teaches me something new.

- I am allowed to decide on the methods for doing the work.

- I believe that the management cares about the health and safety of employees.

- I get the opportunity to mix with my colleagues and to communicate on aspects of our work.

- I am given work in accordance with my qualifications and skills.

- My supervisor shows a genuine interest in motivating me

- I believe that my supervisor will support me if there are problems. 